\title{
A Comparative Study of China and the US Delisting System
}

\author{
Yanru Zhou \\ Jinan University, Guangzhou, China \\ Email: yanru20120401@163.com
}

How to cite this paper: Zhou, Y.R. (2017) A Comparative Study of China and the US Delisting System. American Journal of Industrial and Business Management, 7, 855863.

https://doi.org/10.4236/ajibm.2017.77060

Received: June 7, 2017

Accepted: July 3, 2017

Published: July 6, 2017

Copyright $\odot 2017$ by author and Scientific Research Publishing Inc. This work is licensed under the Creative Commons Attribution International License (CC BY 4.0).

http://creativecommons.org/licenses/by/4.0/

c)

\begin{abstract}
The difficulty of delisting is an urgent problem to be solved in China's securities market. Whether the delisting mechanism is smooth is the touchstone to measure the maturity of the securities market. This paper makes a comparative analysis of the delisting system in China and the United States from the angle of the standard and procedure of delisting and the effect of implementation. It is found that the effect of the delisting system in China is not good, and the delisting system is not the same, then analyzes the reasons of the difference between the implementation effect of China-US delisting system. This paper holds that the standard of delisting has been basically established, but it needs further improvement, and the special treatment period should be abolished in the delisting procedure. In addition, we should improve the legal standards, increase punishment, gradually implement the registration system, and give full play to the role of "barometer" of the securities market. I hope to provide reference for the further improvement of China's delisting system.
\end{abstract}

\section{Keywords}

Delisting System, ST, Registration System

\section{Introduction}

Since the establishment of China's securities market in 1990, it has gone through 26 years, the market degree of securities is increasing, and all kinds of laws and regulations have been established and perfected. So far it has gradually formed three independent development of the plate including main board, small plates and the GEM. This paper mainly studies the main board and small plates. As of December 31, 2016, the Shanghai Stock Exchange and the Shenzhen Stock Exchange listed a total of 2800 . The total market value is more than 51 trillion yuan. However, compared with other relatively mature securities market, China of the securities market has many mechanisms need to be improved, such as the 
development of China's securities market delisting system to be improved. Listing refers to the process of listing the company in order to obtain funds to expand the development of the stock exchange through the initial public offering of shares to investors. Delisting, as the name suggests, refers to the non-eligible companies to withdraw from the original trading place, which enters the market or even completely out of the transaction process. From the US securities market development experience, delisting system and the listing system should be balanced development, but China's delisting system is far behind the listing system. Since the 1994's "Company Law" and the 1999 "Securities Law" initially established listed companies delisting system, our country's delisting system is constantly improving. In 2001, the CSRC issued the measures to suspend listing and terminate the listing of the listed companies, and the 2012 Shanghai Stock Exchange will diversify its index, and the CSRC issued a few opinions on reforming and perfecting the delisting system of listed companies in 2014, which is called "the most strict delisting system in history". However, from 1999 to the present, the Shanghai and Shenzhen Stock Exchange delisting company less than 150. Implementation of the delisting system is to encourage listed companies to survive the fittest, improve the securities market activity, to achieve effective allocation of effective resources, give full play to the market economy "barometer" role. This paper is divided into six parts, the first part of the introduction of the background of the study. The second part is from China and the United States of delisting standards, delisting procedures and implementation effects of comparative analysis. The third part summarizes the reasons of the difference of the effect of the Chinese and American delisting system, and sums up the reasons why the effect of the delisting system is poor. The forth part puts forward own suggestion, hoping to give the reference meaning to our country delisting system. The fifth part is research conclusions and limitations. The sixth part is reference literature.

\section{The Comparison of Delisting Standards, Procedures and the Implementation Effect}

A) Delisting standards

In 2014, China formulated a more stringent delisting system. It mainly related to the following indicators: 1) financial category, including net profit, net assets, operating income, the type of audit opinion; 2) corporate governance, including equity distribution, total equity and so on; 3) market transactions, the cumulative stock volume, stock prices and so on; 4) major illegal categories, including major errors, false records, illegal. 5) other, including the dissolution of the company, the court declared bankruptcy, did not disclose the annual report [1]. NYSE delisting system is as follows: 1) 30 consecutive trading day price of less than 1 US dollars; 2) public holdings less than 60 million shares; 3 ) the number of shareholders less than 400 people; 4) the number of shareholders less than 1200 people and the average volume in the last 12 months less than 10 million shares. If you touch any of the above criteria, companies listed on the NYSE will 
be asked by the NYSE to withdraw from the market, and the financial test standards that do not meet the guidance of the listed company will face delisting. The Nasdaq Securities market must also meet the basic requirements of "continuing listing" and meet the standards of shareholders' equity, total market capitalization, total assets, total revenue and market makers [2].

At present, our country and the United States of the criteria used in the market are generally consistent, but there are some differences. First of all, China's delisting standards over-emphasis on financial indicators. The implementation of standards is too simple, easier to manipulate. It cannot give full play to the new features of the securities market such as net profit. If two-year net profit is negative, the company enter into the special treatment period. The standard even are the Chinese listed companies delisting the main criteria. While other market-oriented indicators such as liquidity, stock trading volume, transaction price are not included in the standards. Although the NYSE and Nasdaq's delisting standards also have financial indicators, because of the existence of multiple standards, financial indicators are not the main. They pay more attention to the corporate governance and market transactions, such as public ownership, stock price and so on. Second, although the delisting system of China's delisting standards has been established, compared to the US delisting standards, China's delisting standards are not enough to quantify, such as major or too low general terms, more the reliance on the subjective judgment of the practitioners, the objectivity and the operability of the delisting process are weakened.

\section{B) Delisting procedures}

The delisting procedure of Chinese listed companies begins with special treatment, including ST and ${ }^{*}$ ST. ST means that the company's performance does not meet the standards. The Stock Exchange is mandatory or the company applies for special treatment, in front of the company name ST. ${ }^{\star} \mathrm{ST}$ is theStock Exchange on the risk of the company in the ST on the basis of the implementation of the means of treatment, in front of the company name ${ }^{*} \mathrm{ST}$. The implementation of ST or ${ }^{*}$ ST company performance if it can be improved, you can apply to the Stock Exchange to revoke ST. However, if the performance cannot be improved, the company will face the suspension of listing. After the suspension of listing according to the business situation can be listed or to terminate the listing, to restore the listing that is restored to ST or ${ }^{*} \mathrm{ST}$ state, the termination of the market is transferred to the OTC market or out of the trading market. NYSE and Nasdaq did not have a special treatment period, once found that the company does not meet the listing standards, the Stock Exchange will immediately notify the listed companies to implement delisting procedures, directly into the off-site quotation bulletin board market transactions.

Contrast shows that in the delisting process, the biggest difference betweenChina and the United States is the special treatment stage of the existence of this buffer period. So, many do not meet the listing standards of poor companies get breathing opportunities, through a series of means, such as asset restructuring, manipulation of non-recurring gains and losses to remove the ST or ${ }^{\star} \mathrm{ST}[3]$. The 
existence of the buffer period makes the delisting of China's delisting standards greatly reduced.

C) The effect of implementation

1) The number of delisting

China's securities market from 1999 to the end of 2016, the overall number of maintenance in 2800 or so, a total of 104 delisting, the annual delisting of 5, not including the board listed companies, total listed 2281, the annual listing of 126, listed companies are increasing the overall trend. The United States has the world's most mature securities market, delisting system is also very perfect. NYSE and Nasdaq's current number of listed companies remained stable, the NYSE to maintain the overall number of 2300 or so, the number of delisting listed each year to maintain the number of $100-200$ or so, the number of listed companies did not change much The Nasdaq overall quantity maintained at around 3000, the number of delisting each year $200-300$ or so, $100-200$ listed companies, the total number of listed companies showed a downward trend. Comparison shows that the number of listed companies in China is very small, 18 years of delisting less than the NYSE or Nasdaq a year of withdrawal.

2) Delisting Way

Delisting in accordance with the wishes of the city can be divided into passive delisting and active delisting, passive delisting is that the listed companies do not conform to the listing standards by the Exchange to stop the listing, the active delisting is the listed company in order to achieve maximum benefits and actively to the stock exchange to apply for delisting behavior. In our country delisting 104 companies, because of the continuous loss of the city has 51, the privatization of 9 , the absorption of the merger of 36 , the suspension of the listing did not disclose the financial report 3 , securities replacement 2 , illegal disclosure of 1 home. China's delisting companies early concentrated on the passive retreat, after focusing on the active retreat.

In addition to the delisting system in the United States has a good implementation effect in the number of delisting companies, in the delisting of the company delisting way also has a very good effect. In addition to the listed companies in the United States does not meet the criteria for the continuous listing of the passive delisting, many companies will be out of their own development strategy, cost savings and other options to withdraw from the initiative. According to Macey, O'Hara, Pompilio (2004) statistics, from 1998 to 2002, in the NYSE delisting of the company, the passive delisting 268, take the initiative to withdraw 839, Nasdaq Passive delisting 1839, take the initiative to withdraw from the market 1512, see the Table 1 and Table 2.

Comparing the way of delisting, we can know that the delisting method adopted by the listed companies in our country is different from that of the United States, and the reason of the early passive retreat is mainly due to the continuous loss, and then the active retreat is absorbed and merged, but even if companies retreat to the market by absorbing mergers, these companies concentrate on resources such as steel or aluminum, and more for some state-owned 
Table 1. NYSE delisting mode.

\begin{tabular}{cccc}
\hline & passive delisting & Initiative delisting & total \\
\hline 1998 & 29 & 180 & 209 \\
1999 & 50 & 204 & 254 \\
2000 & 61 & 225 & 286 \\
2001 & 65 & 148 & 213 \\
2002 & 63 & 82 & 145 \\
total & 268 & 839 & 1107 \\
\hline
\end{tabular}

Data source: Wind database, organized by the author.

Table 2. Nasdaq delisting mode.

\begin{tabular}{cccc}
\hline & passive delisting & Initiative delisting & total \\
\hline 1998 & 489 & 280 & 769 \\
1999 & 440 & 433 & 873 \\
2000 & 240 & 235 & 475 \\
2001 & 390 & 275 & 665 \\
2002 & 280 & 289 & 569 \\
total & 1839 & 1512 & 3351 \\
\hline
\end{tabular}

Data Sources: Jonathan Macey, Maureen O'Hara, David Pompilio. Down and Out in the Stock Market: The Law and Finance of the Delisting Process. Cornell University, 2004 [4].

enterprises to integrate the resources of the industry, it is not that the securities market is playing the role of the fittest. And the NYSE adopts the way of active retreat, the Nasdaq is basically flat, the reason of delisting is also different, the American company because the stock price is below 1 US dollar namely the existence of the standard, the company adopts and shares or privatization or the way to realize the market. From the mature market of the United States, the active delisting can reflect the maturity of a stock market delisting system, which is the performance of the fittest, and the delisting system of China's securities market has not reached such a degree at present.

3) The implementation of ST and revocation ST

China's securities market compared to the United States mature market, the most characteristic is the existence of special treatment period, to China's securities market has a far-reaching impact. The author of the 1999-2016 implementation of ST and revocation ST of the company statistics, found a total of 820 companies were implemented St, each year 45 companies were implemented St, 683 companies have been revoked St, each year 37 companies have been revoked, it is known that the existence of the special treatment period of most of the implementation of St company has about $83 \%$ of the probability of being revoked St, also from another point of view of our country's delisting system there are many areas to be improved, see the Table 3. 
Table 3. Implementing ST and revocation ST.

\begin{tabular}{|c|c|c|c|}
\hline & Implementing ST & Revocation ST & Revocation ST/Implementing ST \\
\hline 1999 & 37 & 5 & $13.51 \%$ \\
\hline 2000 & 31 & 20 & $64.52 \%$ \\
\hline 2001 & 25 & 19 & $76.00 \%$ \\
\hline 2002 & 52 & 17 & $32.69 \%$ \\
\hline 2003 & 67 & 17 & $25.37 \%$ \\
\hline 2004 & 45 & 32 & $71.11 \%$ \\
\hline 2005 & 36 & 43 & $119.44 \%$ \\
\hline 2006 & 64 & 22 & $34.38 \%$ \\
\hline 2007 & 69 & 36 & $52.17 \%$ \\
\hline 2008 & 29 & 48 & $165.52 \%$ \\
\hline 2009 & 34 & 34 & $100.00 \%$ \\
\hline 2010 & 41 & 23 & $56.10 \%$ \\
\hline 2011 & 17 & 36 & $211.76 \%$ \\
\hline 2012 & 27 & 72 & $266.67 \%$ \\
\hline 2013 & 25 & 79 & $316.00 \%$ \\
\hline 2014 & 49 & 53 & $108.16 \%$ \\
\hline 2015 & 90 & 79 & $87.78 \%$ \\
\hline 2016 & 82 & 48 & $58.54 \%$ \\
\hline total & 820 & 683 & $83.29 \%$ \\
\hline average & 45 & 37 & $83.29 \%$ \\
\hline
\end{tabular}

Data source: Wind database, organized by the author.

\section{The Reasons for the Differences in the Implementation of the Delisting System between China and the United States}

A) The reasons for the poor implementation of the delisting system in China

From our country in 18, the number of delisting is only 104 compared to the NYSE and NASDAQ each year, the number of delisting can reach about 100 200 of the situation, the reason for the poor implementation effect of the delisting system in China lies in the uniqueness of the "shell" resources. First of all, the narrow channel of direct financing in our country at present, and the development of the Sanban market and OTC market in our country is relatively backward, and the direct financing of enterprises depends on the stock exchange. However, the total supply of the distribution market is not matched with the financing demand of the rapid economic growth, and a large number of enterprises are listed in line, which causes the difficulty of listing and the "shell" resource is difficult to obtain.

Second, the listed companies enjoy a lot of development dividends, such as the governance of listed companies transparent, operating relative norms, in the direct financing, credit financing and other areas have more opportunities. In the 
case of the "shell" value of listed companies, local governments, shareholders, reorganization parties, creditors and other factors are unwilling to see the situation of the company retreat, so the delisting system is also a nominal.

B) The reasons for the effective implementation of the US delisting system

NYSE and NASDAQ, the number of delisting is higher than our country and take the initiative to withdraw the way the company is mostly. Such a high number of delisting cannot be separated from the strict legal system of the United States, since Enron and WorldCom accounting fraud scandal exposure, in 2002, the United States enacted Sarbanes-Oxley Act, Sarbanes-Oxley Act, Sarbanes-Oxley Act 302 requires the company's CEO and CFO to ensure the fairness and legality of financial reporting, 404 of the requirements of the management must be the company's internal control to make an evaluation, and require the Certified Public accountants to issue a report. The Sarbanes-Oxley Act increases the listing costs of listed companies and requires a great deal of manpower and financial resources, and the Sox act is punishable by a maximum penalty of \$5 million and \$25 million for personal and corporate fraud offences in 25 years imprisonment for intentional securities fraud. So, in the face of such a high cost of listing, many companies are struggling to make ends meet, the United States companies are afraid of financial fraud, once found will face huge fines and criminal penalties, so many companies choose to opt out of the market.

Second, the United States does not have "shell" this argument, the US delisting system in the focus on corporate governance and market transaction indicators, corporate governance and market transaction indicators are not as easy to be controlled as net profits, so if not meet the listing standards, can only retire the city, and the United States issued new shares when the means are registered system, the proposed listing of the company's profit is not strict requirements, the Government does not control the listing quota, the listing difficulty is far less than China, which makes "shell” resources and not much value [5].

\section{Policy Recommendations}

A) To improve the standards of delisting

China's delisting standards compared to the United States is not very different, but there are many deficiencies, the first to establish a multi-level delisting standards, improve corporate governance, market transactions and other indicators, the number of shareholders, equity dispersion, and so on, no longer the financial indicators as a measure of the main criteria for delisting. Second, improve the quantitative standards, the abolition of the standard is similar to "significant" or "too low" and so on, to minimize subjective judgments, so that each standard is more enforceable. Like what kind of mistake is a big mistake, what's too low [6].

B) To cancel the special treatment period

The biggest difference between China's delisting procedure and US delisting procedure is the existence of special treatment period, and the existence of spe- 
cial treatment period weakens the effect of delisting system implementation. is not conducive to the stability of the capital market, cannot really achieve the survival of the fittest, the actual situation of our country, the gradual clean-up by St. Inferior company, the company does not meet the listed standards of passive retreat, after the cancellation of special treatment period, learning foreign direct delisting procedures, enhance the implementation of the delisting.

C) To improve the legal standards

The legal standard of our country is not strict enough to the American information disclosure, and it is not enough to punish the behavior such as false cheating, for the financial report is only to require the audit report issued by the $\mathrm{CPA}$ as a negative opinion or not to express opinions, the securities law for false statements, misleading and major loopholes in the maximum penalty of only 600,000 , the main responsible for the punishment of only 300,000 , the punishment is not enough. For internal control, although it is also mandatory to require companies to publish internal control self-evaluation report, but it is undeniable that many companies have the same phenomenon of self-evaluation reports, cannot avoid the suspicion of plagiarism. Perfecting the legislative system and increasing the legal mechanism of CPA or company executives. "Securities law" on the principal responsible for the punishment is difficult to really play a deterrent role, you can consider increasing penalties, so that the company and the main officials from "do not do" to "do not want to do", effectively suppress the occurrence of illegal information disclosure, and then promote the effective implementation of China's delisting system.

D) To implement the registration system

The main reason for the poor implementation of the delisting system in China is the scarcity of the "shell" resources due to the adoption of the approval system, and the problem of listing is not solved. Delisting system is also difficult to solve, after the implementation of the registration system, direct financing channels to expand, the company's listing difficulty, the "shell" resources will be reduced the value of the face of some worthless "shell" Resources, St Company, the Government, shareholders and other insurance "shell" motives will also decline. The construction of a more transparent, freer and more market-oriented registration system is conducive to the implementation of the delisting system and has far-reaching significance to our country's capital market.

\section{Research Conclusion and Limitations}

Starting from the market phenomenon of delisting, this paper makes a full comparison between the delisting criteria, delisting procedures and the effect of delisting in the US delisting system. The paper also analyzes the reasons of the delisting system and the efficient operation of the American delisting system, and then suggests that we should constantly improve the delisting standard, cancel the special treatment period, perfect the legal standard and implement the registration system. I hope to provide some reference for our country's delisting system. However, the article also has the insufficient part. Firstly, because the data 
source is limited, for the US active delisting and the passive retreat City company data only found 1998-2002. Secondly, the change of any national system is not a matter of time, although a lot of deficiencies and needs to improve the place, but China's delisting system still have a long way to go, and due to the particularity of China's national conditions, we cannot completely copy the United States delisting system. We should find a delisting system that is suitable for China in constant exploration.

\section{References}

[1] Ding, D. and Hou, F.K. (2014) The Reform of Delisting System of Listed Companies: Problems, Policies and Prospects. Social, 1, 109-117.

[2] Macey, J., O'Hara, M. and Pompilio, D. (2008) Down and Out in the Stock Market: The Law and Economics of the Delisting Process. The Journal of Law and Economics, 51, 683-713. https://doi.org/10.1086/593386

[3] Wei, T., Lu, Z.F. and Shan, H.W. (2007) Research on Motives, Means and Functions of Non-Recurrent Profit and Loss Earnings Management-Empirical Evidence from Listed Companies in China. Managing the World, 1, 113-121.

[4] Macey, J., O'Hara, M. and Pompilio, D. (2004) Down and Out in the Stock Market: The Law and Finance of the Delisting Process. Cornell University.

[5] Ni, X. (2009) The Government's Behavior in the Supply and Change of Delisting System. Managing the World, 11, 168-169.

[6] Li, Z.R. (2008) Perfecting the Delisting System of China's Listed Companies. Financial Research, 11.

Submit or recommend next manuscript to SCIRP and we will provide best service for you:

Accepting pre-submission inquiries through Email, Facebook, LinkedIn, Twitter, etc. A wide selection of journals (inclusive of 9 subjects, more than 200 journals)

Providing 24-hour high-quality service

User-friendly online submission system

Fair and swift peer-review system

Efficient typesetting and proofreading procedure

Display of the result of downloads and visits, as well as the number of cited articles

Maximum dissemination of your research work

Submit your manuscript at: http://papersubmission.scirp.org/

Or contact ajibm@scirp.org 